\title{
FACTORS INFLUENCE THE BEHAVIOR OF BULLYING AT THE STUDENTS OF SMK PGRI 8 MEDAN IN 2015
}

\author{
Endang Susilawati, Syarif Zen Yahya, Wenny F Simanjuntak \\ Jurusan Keperawatan Kemenkes Medan
}

\begin{abstract}
Abstrak
Bullying is aggressive behavior intentionally to attack the target or victim in weak position, easy for insulted and can not self defense. The characteristic of children that influence the sensitivity of childrento do the bullying in school. Factors influence the bullying behavior is personality, peers, school climate. This research aims toi study factors influence the bullying behavior at SMK PGRI 8 Medan. The design of this research is descriptive study using cross sectional approach. The population in this research is students of SMK PGRI 8 Medan for the number of 164 students. The sample is take by accidental sampling for the sample is 35 students by the measurement tool is questionnaire. The result of research indicates that factors of personality, peer, and school climate influence the behavior of bullying of anyone. Based on research, the dominant factor is school climate and peer. Based on the result of research indicates that the bullying in mild category is 14 respondents (40\%), medium is 11 respondents $(31,4 \%)$ and severe is 10 respondents $(28,6 \%)$. It is suggested to the student to increase their knowledge about bullying, follow the value and norm applied in school, and develop the empathy, faith on God and build a good communication or relationship to the peer and teacher.
\end{abstract}

Kata kunci : bullying, personality, peer, school climate

\section{Latar Belakang}

Maraknya kasus-kasus kekerasan yang terjadi pada anak-anak usia sekolah saat ini sangat memprihatinkan bagi pendidik dan orangtua. Sekolah yang seharusnya menjadi tempat bagi anak menimba ilmu serta membantu membentuk karakter pribadi yang positif ternyata malah menjadi tempat tumbuh suburnya praktek-praktek bullying, sehingga memberikan ketakutan bagi anak untuk memasukinya. Kekerasan atau bullying di institusi pendidikan bisa dilakukan oleh siapa saja, baik antar teman, antar siswa, antar geng di sekolah, kakak kelas, bahkan guru. Lokasi kejadiannya mulai dari ruang kelas, toilet, kantin, halaman, pintu gerbang, bahkan di luar pagar sekolah. Akibatnya, sekolah bukan lagi tempat yang menyenangkan bagi siswa, tetapi justru menjadi tempat yang menakutkan dan membuat trauma (Mudjijanti, 2011).

Bullying adalah penghambat besar bagi seorang anak untuk mengaktualisasikan diri. Bullying tidak memberi rasa aman dan nyaman, membuat para korban bullying merasa takut dan terintimidasi, rendah diri serta tak berharga, sulit berkonsentrasi dalam belajar, tidak bergerak untuk bersosialisasi dengan lingkungannya, enggan bersekolah, pribadi yang tidak percaya diri dan sulit berkomunikasi, sulit berpikir jernih sehinggaprestasi akademisnya dapat terancam merosot. Mungkin pula, para korban bullying akan kehilangan rasa percaya diri kepada lingkungan yang banyak menyakiti dirinya (Sejiwa, 2008).
Banyak anak mengkhawatirkan apakah dia populer atau tidak di lingkungannya. Anak populer sering dianggap sebagai teman baik dan jarang tidak disukai oleh teman sebaya mereka. Anak - anak populer memberikan penguatan, mendengarkan dengan seksama menjaga komunikasi yang terbuka dengan teman sebaya, bahagia, bertindak sebagaimana adanya, menunjukan antusiasme dan perhatian terhadap orang lain serta percaya diri tanpa bersikap sombong (Santrock, 2007).

Peristiwa penindasan di lingkungan sekolah (school bullying) menurut Riauskina dkk, dalam Siti (2012) yaitu perilaku agresif yang di lakukan berulangulang oleh seorang atau sekelompok siswa yang berkuasa terhadap siswa-siswi yang lemah, dengan tujuan menyakiti orang tersebut.

Departemen kehakiman Amerika Serikat mengeluarkan hasil statistik yang mencengangkan bahwa $77 \%$ pelajar Amerika Serikat mengalami bullying baik secara fisik, verbal maupun mental. Ini berarti 1 dari 4 anak di negri tu telah terkena bullying (Sejiwa, 2008).

Di Indonesia sendiri masih sedikit data yang menjelaskan mengenai angka kejadian bullying di sekolah. Sebuah studi menyebutkan bahwa $67 \%$ pelajar di kota-kota besar dikota Indonesia menyatakan bahwa di sekolahnya terjadi bullying.Tentang kekerasan bullying di tiga kota besar di Indonesia, yaitu Yogyakarta, Surabaya, dan Jakarta mencatat terjadinya tingkat kekerasan sebesar $67,9 \%$ di tingkat Sekolah 
Menengah Atas (SMA) dan 66,1\% di tingkat Sekolah Menengah Pertama (SMP). Kekerasan yang dilakukan sesama siswa tercatat sebesar $41,2 \%$ untuk tingkat SMP dan $43,7 \%$ untuk tingkat SMA dengan kategori tertinggi kekerasan psikologis berupa pengucilan. Peringkat kedua ditempati kekerasan verbal (mengejek) dan kekerasan fisik (memukul) (Sejiwa, 2008)

Bullying secara psikologis juga dialami oleh siswa seperti difitnah atau digosipkan (92,99\%), dipermalukan di depan umum $(79,65 \%)$, dihina atau dicaci $(44,25 \%)$, dituduh $(38,05 \%)$,disoraki $(38,05 \%)$ bahkan diancam

$(33,62 \%)$

(http://kesehatan.kompas.com/21/2/

09) dalam Ulfah 2011).

Salah satu kasus bullying di Indonesia yang pernah dimuat di berbagai media masa adalah kasus Fifi Kusrini, seorang siswi SMP yang berusia 13 tahun di Kab. Bekasi, yang bunuh diri dengan menggantung dirinya karena teman- temannya sering mengejek pekerjaan ayahnya yang seorang penjual bubur (Asep , 2013).

Sebagai kota pelajar, cukup mencengangkan bahwa ternyata di Yogyakarta, untuk tingkat SMP dan SMA kasus bullying termasuk yang paling tinggi dibandingkan Jakarta dan Surabaya ( 70,65\%) ( Ulfah 2011).

Berdasarkan penelitian Yayasan Semai Jiwa Amini (Sejiwa), ternyata bullying masih kurang disadari sepenuhnya oleh para guru. Penelitian dilakukan terhadap guru- guru di 3 SMA di dua kota besar di Pulau Jawa menunjukkan 1 dari 5 guru menganggap penggencetan dan olok-olok adalah hal biasa dalam kehidupan remaja dan tak perlu diributkan. Selain itu, 1 dari 4 guru berpendapat bahwa sesekali penindasan tidak akan berdampak buruk pada kondisi psikologi siswa. Sebuah studi yang dilakukan oleh ahli pendidikan Amy Huneck hanya ada 1 dari 10 orang dewasa yang diwawancarai merasa bullying adalah masalah.

Perilaku bullying paling sering terjadi pada masa-masa sekolah menengah atas (SMA), dikarenakan pada masa ini remaja memiliki egosentrisme yang tinggi (Irvan, 2013).

Identitas kelompok dan pergaulannya, bisa mengesampingkan identitas pribadi remaja. Di sekolah menengah mana pun, seringkali ada tiga sampai enam kelompok yang terbentuk. Meskipun banyak remaj ingin masuk kedalam satu kelompok, beberapa remaja bisa mandiri dan tidak memiliki keinginan untuk masuk kedalam sebuah kelompok (Santrock, 2007).

Persahabatan cenderung memainkan peran perkembangan yang lebih penting di sekolah menengah ketimbang di sekolah dasar. Para remaja menyingkap informasi yang lebih pribadi kepada teman-teman merka daripada anak- anak yang lebih muda. Para remaja pun mengatakan bahwa mereka lebih bergantung pada teman-teman mereka daripada dengan orang tua mereka, untuk memuaskan kebutuhan pertemanan, perasaan berharga dan keintiman (Santock, 2007).

Penelitian yang dilakukan oleh Siswati, (2009) dengan judul "Fenomena Bullying di sekolah Dasar Negeri Semarang.Total sampel dari penelitian ini adalah 78 murid dari kelas 3 sampai kelas 6. Hasil penelitian menunjukan bahwa $37,55 \%$ murid menjadi korban dari bullying. 42,5\% murid menderita karena disebabkan oleh bullying mental/psikologis.

Dari hasil survey pendahuluan di SMK PGRI 8 Medan pada kelas 11 ada 164 sisiwa rata-rata siswa - siswi pernah melakukan bullying baik secara verbal, psikologis, dan fisik. Diketahui bahwa enam dari sepuluh orang siswa yang duduk di kelas 11 SMK dinyatakan pernah melakukan bullying terhadap siswa lain dan dua orang lainnya menjadi korban bullying. Sedangkan 2 siswa lainnya tiak pernah mengalami atau melakukan bullying terhadap siswa - siswi lainnya. Dalam studi pendahuluan ini dilakukan dengan wawancara dengan guru bimbingan penyuluhan (BP). Maka dari beberapa faktor diyakini menjadi penyebab terjadinya perilaku bullying di sekolah, antara lain adalah faktor kepribadian, kelompok teman sebaya dan iklim sekolah. Oleh karena itu penelitian untuk aspek apapun yang berkaitan dengan masalah bullying akan memberi konstribusi terhadap penanganan masalah bullying diindonesia. Maka sangat layak jika kemudian dipertanyakan bagaimana masalah bullying disekolah sekolah indonesia? Bertolak dari kenyataan tersebut, penulis terdorong untuk meneliti tentang gambaran fenomena yang terjadi dalam populasi tertentu, dengan pendekatan cross sectional yaitu suatu metode yang merupakan rancangan penelitian dengan melakukan pengukuran atau pengamatan pada saat bersamaan ( sekali waktu ) (Notoatmodjo, 2012).

\section{AlatUkur}

Cara pengumpulan data pada variabel independen maupun dependen adalah dengan kuesioner pengukurannya dengan cara check list dengan skala Guttman.

Untukpernyataan score: Nilai 1 = ya Nilai $0=$ tidak

\section{Hasil dan Pembahasan}

\begin{tabular}{ccc}
\hline Jenis Kelamin & F & \% \\
\hline Laki-Laki & 7 & $20 \%$ \\
Perempuan & 28 & $80 \%$ \\
\hline Total & $\mathbf{3 5}$ & $\mathbf{1 0 0 \%}$ \\
\hline
\end{tabular}

\section{Metode Penelitian \\ Jenis dan Desain Penelitian}

Penelitian ini merupakan penelitian yang bersifat deskriptif yaitu suatu metode penelitian yang dilakukan dengan tujuan melihat. 
Berdasarkan tabel 4.2.1 responden berdasarkan jenis kelamin didapatkan laki-laki 7 responden $(20 \%)$ dan perempuan 28 responden $(80 \%)$.

Distribusi Frekuensi Responden Berdasarkan umur DiSMK PGRI 8 Medan Tahun 2015

\begin{tabular}{ccc}
\hline Umur & F & \% \\
\hline 14 tahun & 5 & $14,3 \%$ \\
15 tahun & 16 & $45,7 \%$ \\
16 tahun & 14 & $40 \%$ \\
\hline Total & $\mathbf{3 5}$ & $\mathbf{1 0 0 \%}$ \\
\hline
\end{tabular}

Berdasarkan tabel 4.2.2 responden berdasarkan umur didapat berumur 16 tahun ada 14 responden $(40 \%)$,

15 tahun ada 16 responden $(45,7 \%)$,

14 tahun ada 5 responden $(14,3 \%)$

Distribusi Frekuensi Responden Berdasarkan Perilaku Bullying Di SMK PGRI 8 Medan Tahun 2015

\begin{tabular}{ccc}
\hline Bullying & F & \% \\
\hline Berat & 10 & $28.6 \%$ \\
Sedang & 11 & $31,4 \%$ \\
Ringan & 14 & $40 \%$ \\
\hline Total & $\mathbf{3 5}$ & $\mathbf{1 0 0}$ \\
\hline
\end{tabular}

Berdasarkan tabel 4.2.3 responden yang berperilaku bullying dikatakan berat sekitar 10 responden $(28,6 \%)$, dikatakan sedang sekitar 11 responden $(31,4 \%)$ dan dikatakan ringan sekitar 14 responden $(40 \%)$.

Distribusi Frekuensi Responden Berdasarkan Kepribadian Di SMK PGRI 8 Medan Tahun 2015

\begin{tabular}{ccc}
\hline Kepribadian & F & \% \\
\hline Baik & 25 & $71,4 \%$ \\
Buruk & 10 & $28,6 \%$ \\
\hline Total & $\mathbf{3 5}$ & $\mathbf{1 0 0}$ \\
\hline
\end{tabular}

Berdasarkan tabel 4.2.4 dapat dilihat bahwa faktor yang memengaruhi bullying berdasarkan kepribadian baik 25 responden $(71,4 \%)$ dan buruk 10 responden $(28,6 \%)$.

Distribusi Frekuensi Responden Berdasarkan Teman Sebaya DiSMK PGRI 8 Medan Tahun 2015

\begin{tabular}{rcc}
\hline Teman Sebaya & F & \% \\
\hline Baik & 13 & $37.1 \%$ \\
Buruk & 22 & $62,9 \%$ \\
\hline Total & $\mathbf{3 5}$ & $\mathbf{1 0 0}$ \\
\hline
\end{tabular}

Berdasarkan tabel 4.2.5 dapat dilihat bahwa faktor yang memengaruhi bullying berdasa

\begin{tabular}{|c|c|c|}
\hline berpengaruh & baik 13 & responden \\
\hline$(37,1 \%)$ dan & teman & sebaya \\
\hline berpengaruh & buruk 22 & responden \\
\hline
\end{tabular}

Distribusi Frekuensi Responden Berdasarkan Iklim Sekolah di SMK PGRI 8 Medan Tahun 2015

\begin{tabular}{ccc}
\hline Iklim Sekolah & F & \% \\
\hline Baik & 23 & $65,7 \%$ \\
Buruk & 12 & $34,3 \%$ \\
\hline Total & $\mathbf{3 5}$ & $\mathbf{1 0 0}$ \\
\hline
\end{tabular}

Berdasarkan tabel 4.2.6 dapat dilihat bahwa faktor yang memengaruhi bullying berdasarkan iklim sekolah yang baik 23 responden $(65,7 \%)$ dan iklim sekolah berpengaruh buruk 12 responden $(34,3 \%)$.

Distribusi Frekuensi Responden Berdasarkan Kepribadian terhadap perilaku bullying Di SMK PGRI 8 Medan Tahun 2015

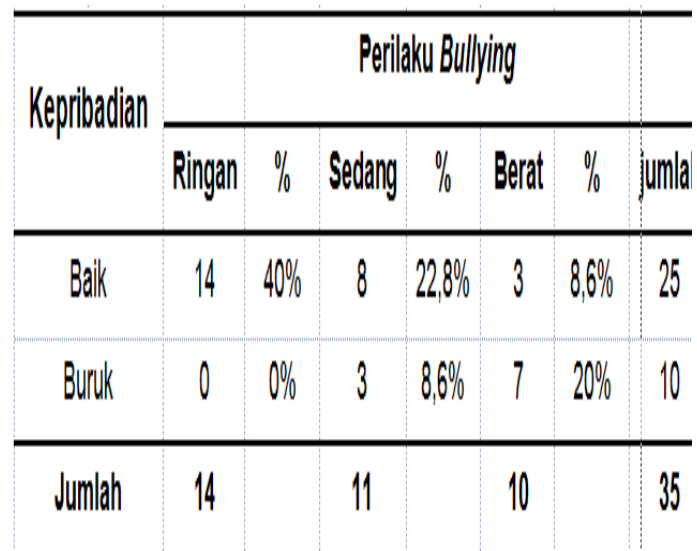

Berdasarkan tabel 4.2.7 siswa yang berkepribadian baik perilaku bullying yang dilakukan bullying ringan 14 responden (40\%) dan sedang 8 responden $(22,8 \%)$ sedangkan kepribadian buruk perilaku bullying yang dilakukan bullying sedang 3 responden $(8,6 \%)$ dan berat 7 responden $(20 \%)$. Dilihat dari hasil penelitian kepribadian yang buruk memilki pengaruh dalam perilaku bullying. 
Distribusi Frekuensi Responden Berdasarkan Teman Sebaya terhadap perilaku bullying Di SMK PGRI 8 Medan Tahun 2015

\begin{tabular}{c|r|r|r|r|r|r|r}
\hline \multirow{2}{*}{$\begin{array}{c}\text { Teman } \\
\text { Sebaya }\end{array}$} & \multicolumn{5}{|c|}{ Perilaku Bullying } & \\
\cline { 2 - 8 } & Ringan & $\%$ & Sedang & $\%$ & Berat & $\%$ & jumlah \\
\hline Baik & 8 & $22,8 \%$ & 4 & $11,5 \%$ & 1 & $2,8 \%$ & 13 \\
\hline Buruk & 6 & $17,2 \%$ & 7 & $20 \%$ & 9 & $25,7 \%$ & 22 \\
\hline Jumlah & 14 & & 11 & & 10 & & 35 \\
\hline
\end{tabular}

Berdasarkan tabel 4.2.6 teman sebaya yang berpengaruh baik perilaku bullying dilakukan bullying ringan 8 responden $(22,8 \%)$ dan sedang 4 responden $(11,5 \%)$ sedangkan teman sebaya yang berpengaruh buruk perilaku bullying dilakukan bullying sedang 7 responden (20\%) dan bullying berat responden $(25,7 \%)$. Dilihat dari hasil penelitian teman sebaya yang buruk memiliki pengaruh dalam perilaku bullying.

Distribusi Frekuensi Responden Berdasarkan Iklim Sekolah Terhadap Perilaku Bullying DiSMK PGRI 8 Medan Tahun 2015

\begin{tabular}{|c|c|c|c|c|}
\hline Teman & \multicolumn{3}{|c|}{ Perilaku Bullying } & \\
\hline Selaya & Ringan $\%$ & Sedany $\%$ & Berat \% & $\overline{\text { Imlah }}$ \\
\hline Baik & $8228 \%$ & $411,5 \%$ & 12,804 & 13 \\
\hline Buruk & $617,2 \%$ & $120 \%$ & $925,7 \%$ & 22 \\
\hline Jumlah & 14 & 11 & 10 & 35 \\
\hline
\end{tabular}

Berdasarkan tabel 4.2.9 iklim sekolah yang baik perilaku bullying dilakukan bullying ringan 13 responden $(37,2 \%)$ dan bullying sedang 10 responden $(28,6 \%)$, sedangkan iklim sekolah yang buruk perilaku bullying dilakukan bullying berat 10 responden $(28,6 \%)$. Dilihat dari hasil penelitian iklim sekolah yang buruk memiliki pengaruh dalam perilaku bullying

\section{Pembahasan \\ Perilaku Bullying}

Penelitian ini dilakukan terhadap 35 responden berdasarkan perilaku bullying di SMK PGRI 8 Medan Tahun 2015 yang cenderung melakukan bullying dengan jenis- jenis perilaku yang berbeda ada yang bullying verbal, fisik dan psikologis. Tingkat perilaku berperilaku bullying dikatakan berat sekitar 10 responden $(28,6 \%)$, dikatakan sedang sekitar 11 responden $(31,4 \%)$ dan dikatakan ringan sekitar 14 responden $(40 \%)$.
Perilaku bullying bukan suatu perilaku yang dengan sendirinya ada di dalam diri manusia tetapi merupakan perilaku yang terbentuk melalui pengalaman, pendidikan yang diperoleh seseorang dalam kehidupannya dan banyak faktor lainnya (Richa, 2013).

Hal ini sejalan dengan hasil penelitian Fitri Yuniartiningtyas (2012) tentang hubungan antara pola asuh dan tipe kepribadian dengan perilaku bullying di Sekolah. Hasil penelitian menunjukkan bahwa perilaku bullying dari 87 orang subjek penelitian yang masuk dalam kategori sangat tinggi 10 orang (12\%), tinggi 8 orang $(9 \%)$, rendah $54(62 \%)$ dan sangat rendah 15 orang (17\%). Dari hasil tersebut maka dapat disimpulkan bahwa sebagian besar perilaku bullying berada dalam kategori rendah. Oleh karena itu, setiap siswa diharapkan untuk berpikir positif, tidak mudah terpengaruh dengan hal negatif dari teman ataupun linkungan sekolah sehingga semakin baik kepribadian siswa, semakin baik komunikasi interpersonal yang akan menjadi peran kelompok teman sebaya untuk mengajak temannya dalam menerapkan norma-norma positif yang ada dalam mayarakat serta semakin kondusif iklim di sekolah maka semakin rendah bahkan tidak ada perilaku bullying.

\section{Kepribadian}

Setelah dilakukan penelitian terhadap 35 responden berdasarkan kepribadian di SMK PGRI 8 Medan Tahun 2015 mayoritas berkepribadian baik. Hal ini karena dari 35 orang didapat berkepribadian baik 25 responden $(71,4 \%)$ dan berkepribadian buruk 10 responden $(28,6 \%)$. Siswa yang berkepribadian baik melakukan bullying ringan 14 responden (40\%) dan sedang 8 responden $(22,8 \%)$ sedangkan kepribadian buruk melakukan bullying sedang 3 responden $(8,6 \%)$ dan berat 7 responden (20\%). Kepribadian baik meiliki 3 responden $(8,6 \%)$ yang berperilaku bullying berat hal ini dikarenakan ada faktor lain yang memengaruhi yaitu teman sebaya dan iklim sekolah yang buruk. Maka dapat disimpulkan bahwa kepribadian yang buruk memilki pengaruh dalam perilaku bullying.

Dalam pertumbuhan dan perkembangannya seringkali kepribadian itu menemukan suatu permasalahan dalam proses pembentukannya. Terdapat faktor- faktor yang selalu mempengaruhi perkembangan yang terjadi dalam pembentukan kepribadian seorang manusia. Oleh karena itu, kepribadian seharusnya menjadi hal yang tidak mutlak! Kepribadian dapat dibentuk dan diusahakan terwujud sesuai dengan bentuk kepribadian yang normal dan adaptif (Dafiq,2012).

Hal ini sejalan dengan hasil dari penelitian Richa Yuswantina (2013), yang meneliti tentang hubungan antara tipe kepribadian anak dengan perilaku bullying.Maka tipe kepribadian yang paling banyak dimiliki oleh siswa kelas VII di SMP Negeri 1 Pati, Kabupaten Pati adalah tipe kepribadian ekstrovert sebanyak 52 siswa $(69,3 \%)$ dan tipe kepribadian introvert sebanyak 23 siswa $(30,7 \%)$. Maka dapat 
disimpulkan bahwa dari siswa yang memiliki tipe kepribadian ekstrovert paling banyak melakukan bullying dibandingkan siswa yang memiliki tipe kepribadian introvert. Oleh karena itu disarankan siswa meninggalkan kepribadian yang buruk menjadi lebih baik seperti bertakwa kepada Tuhan, bersikap lembut, tidak dengki, mengikuti nilai dan norma yang berlaku di lingkungan sekolah atupun diluar sekolah.

\section{Teman Sebaya}

Penelitian juga dilakukan terhadap 35 responden berdasarkan teman sebaya di SMK PGRI 8 Medan Tahun 2015 mayoritas teman sebaya berpengaruh buruk. Hal ini karena dari 35 orang responden teman sebaya yang berpengaruh baik 13 responden $(37,1 \%)$ dan buruk 22 responden $(62,9 \%)$. Teman sebaya yang berpengaruh baik memiliki 1 responden $(2,8 \%)$ berperilaku bullying berat hal ini dikarenakan ada faktor lain yang memengaruhi yaitu kepribadian dan iklim sekolah yang buruk. Terlihat bahwa siswa yang terpengaruh oleh teman sebaya cenderung berperilaku bullying dibandingkan dengan siswa yang tidak terpengaruh oleh teman sebayanya, dapat kita ketahui dari persentase siswa yang tidak terpengaruh 13 responden $(37,1 \%)$ berperilaku bullying ringan 8 responden $(22,8 \%)$ dan sedang 4 responden $(11,5 \%)$ sedangkan siswa yang terpengaruh oleh teman sebaya 22 responden $(62,9 \%)$ berperilaku bullying sedang 7 responden (20\%) dan bullying berat 9 responden $(25,7 \%)$ hal ini menunjukan bahwa ada pengaruh buruk dari teman sebaya.

Kecenderungan mengikuti perilaku teman disebut sebagai konformitas.. Ia akan ikut melakukan, atau membiarkan bullying terus terjadi, meski ia sebenarnya tidak setuju dengan bullying. Konformitas dapat mendukung bullying terus berkembang (Levianti, 2008).

Hal ini sejalan dengan hasil penelitian Irvan Usman (2013), yang meneliti tentang perilaku bullying ditinjau dari peran kelompok teman sebaya dan iklim sekolah pada siswa SMA di kota Gorontalo. Hail penelitiannya terhadap kelompok teman sebaya, terdapat 4 orang $(3,9 \%)$ dalam kategori sangat rendah, sebanyak 3 orang $(2,9 \%)$ yang berada dalam kategori rendah, kategori sedang sebanyak 22 orang $(21,4 \%), 36$ orang $(35,0 \%)$ dalam kategori tinggi, dan sebanyak 38 orang $(36,9 \%)$ dengan kategori yang sangat tinggi. Sesuai dengan hasil penelitian ini teman sebaya memengaruhi untuk melakukan bullying, teman sebaya memilki pengaruh buruk untuk teman-teman yang lain. Oleh karena itu, para siswa hendaknya tidak memandang teman dari status ekonomi, mampu menghargai orang lain, mampu mengembangkan sikap empati, toleransi. Jika siswa memiliki sikap empati yang tinggi berarti siswa tersebut akan merasakan apa yang dirasakan oleh orang lain. Dengan begitu siswa tidak akan mau melakukan tindakan bullying terhadap temannya.

\section{Iklim Sekolah}

Penelitian ini dilakukan juga terhadap 35 responden berdasarkan iklim sekolah di SMK PGRI 8 Medan Tahun 2015 mayoritas iklim sekolah berpengaruh baik. Hal ini karena dari 35 orang responden berpengaruh baik 23 responden $(65,7 \%)$ dan buruk 12 responden $(34,3 \%)$. Iklim sekolah yang baik perilaku bullyingyang dilakukan bullying ringan 13 responden $(37,2 \%)$ dan bullying sedang 10 responden $(28,6 \%)$, sedangkan iklim sekolah yang buruk perilaku bullying dilakukan bullying berat 10 responden $(28,6 \%)$. Dari hasil penelitian ini iklim sekolah yang buruk memiliki pengaruh yang besar dalam perilaku bullying. Maka didapat semakin baik iklim sekolah maka semakin rendah atau ringan perilaku bullying sebaliknya semakin buruk iklim sekolah, semakin tinggi atau berat perilaku bullying yang terjadi.

Iklim sekolah adalah kualitas dan konsistensi dari interaksi interpersonal di dalam komunitas sekolah yang mempengaruhi perkembangan kognitif, sosial dan psikologis siswa. semakin baik kualitas yang dibangun dari interaksi interpersonal antara guru dan siswa di sekolah maka akan mempengaruhi perkembangan kognitif, sosial, dan psikologis siswa ke arah yang lebih baik. Iklim sekolah yang baik ini mengacu pada kondisi pekerjaan antara pimpinan sekolah dan para guru dalam mencapai tujuan objektif tersebut. (Irvan, 2013).

Hal ini sejalan dengan penelitian yang dilakukan oleh Ulfah dan Mira, (2011) yang meneliti tentang hubungan antara iklim sekolah dengan kecenderungan perilaku bullying. pada tingkat cenderung berperilaku bullying sangat rendah 35 orang $(47,94 \%)$, tinggi 1 orang $(1,36 \%)$. Pada tingkat iklim sekolah negatif 2 orang $(2,73 \%)$ dan positif 37 orang $(50,68 \%)$. Maka disimpulkan semakin positif iklim sekolah, semakin rendah kecenderungan perilaku bullying, sebaliknya semakin negatif iklim sekolah, semakin tinggi kecenderungan perilaku bullying. Oleh karena itu untuk mengurangi terjadinya perilaku bullying disarankan sekolah untuk menyediakan pengawasan yang baik untuk anak/siswa, memberikan konsekuensi yang efektif/tegas untuk pelaku. Adanya komunikasi yang baik antara orangtua dan guru, memberi kesempatan pada semua siswa untuk mengembangkan keterampilan interpersonal yang baik, guru memberikan contoh perilaku positif dalam mengajar, melatih, membina, berdoa dan sekolah hendaknya proaktif dengan membuat program manajemen konflik, problem solving, dan pendidikan karakter.

\section{KESIMPULAN DAN SARAN}

\section{Kesimpulan}

1. Hasil penelitian dari 35 responden didapat berdasarkan berperilaku bullying dikatakan berat sekitar 10 responden $(28,6 \%)$, dikatakan sedang sekitar 11 responden $(31,4 \%)$ dan dikatakan ringan sekitar 14 responden $(40 \%)$. 
2. Kepribadian yang paling banyak dimiliki siswa siswi di SMK PGRI 8 Medan adalah kepribadian baik. Kepribadian baik paling banyak melakukan bullying ringan dan sedang sedangkan kepribadian buruk yang melakukan bullying sedang dan berat. Maka dapat disimpulkan kepribadian memengaruhi perilaku bullying seseorang.

Faktor teman sebaya di SMK PGRI 8 Medan menunjukan pengaruh buruk bagi teman- teman sebaya lainnya. Faktor yang memengaruhi bullying berdasarkan teman sebaya berpengaruh baik 13 responden $(37,1 \%)$ dan buruk 22 responden (62,9\%).Teman sebaya yang memengaruhi kearah yang baik paling banyak melakukan bullying ringan dan sedang sedangkan teman sebaya ke arah yang buruk melakukan bullying sedang dan berat. Maka dapat disimpulkan teman sebaya memengaruhi perilaku bullying seseorang.

3. Faktor yang memengaruhi bullying berdasarkan iklim sekolah yang baik ada 23 responden $(65,7 \%)$ dan iklim sekolah berpengaruh buruk 12 responden (34,3\%). Maka dapat disimpulkan semakin baik iklim sekolah maka semakin ringan perilaku bullying, sebaliknya semakin buruk iklim sekolah, semakin berat perilaku bullying yang terjadi.

\section{Saran}

1. Bagi siswa-siswi

Hendaknya bagi siswa meningkatkan pengetahuan mengenai bullying bahwa bullying itu tidak hanya berupa penyerangan secara fisik, tetapi juga secara lisan seperti mengejek, mengikuti nilai dan norma yang berlaku di sekolah, mampu mengembangkan sikap empati, bertakwa kepada Tuhan dan menjaga komunikasi atau hubungan yang baik dengan teman sebaya dan guru.

2. Bagi Sekolah

Meningkatkan pengawasan yang baik untuk anak/siswa, memberikan konsekuensi yang efektif/tegas untuk pelaku, adanya komunikasi yang baik antara orangtua, siswa dan guru, mengembangkan keterampilan yang ada pada siswa-siswinya, memberi kesempatan pada semua siswa untuk mengembangkan keterampilan interpersonal yang baik.

3. Bagi Institusi Pendidikan

Sebagai bahan masukan bagi peneliti lain khususnya keperawatan Poltekkes Kemenkes Medan serta menambah pembendaharaan bacaan dan sebagai referensi informasi dikalangan akademis sebagai dasar pemikiran dan pnelitian selanjutnya.

4. Bagi peneliti

Diharapkan penelitian berikutnya agar dapat mengembangkan penelitian dengan menambah variabel penelitian tentang kecenderungan perilaku bullying dilakukan dengan faktor-faktor lainnya.

\section{DAFTAR PUSTAKA}

Chairilsyah, Dafiq. (2012). Pembentuk Kepribadian Positif Anak Sejak UsiaDini. Jurnal Vol 01.No 01. (diakses tanggal 27 desember 2014).

Gusnarti, U dan Aznan. (2009). Faktor Mempengaruhi Bullying Pada Remaja. Universitas Islam Indonesia Yogyakarta (diakses tanggal 27 Desember 2014).

Krahe, B. (2005). Perilaku Agresif - Buku Panduan Psikologi Sosial. Pustaka Pelajar: Yogyakarta.

Latifah, Fika. (2012). Hubungan Karakteristik Anak Usia Sekolah Dengan Kejadian Bullying Di Sekolah Dasar X Di Bogor. lib.ui.ac.hubungan karakteristik 27 Desember 2014.

Latip, Asep Ediana. (2013). Analisis Faktor-Faktor yang Mempengaruhi Perilaku Bullying Pada Peserta Didik Anak Usia MI/SD. pgmi.fitk.uinjkt.ac.id diakses tanggal 27 Desember 2014.

Levianti. (2008). Konformitas Dan Bullying Pada siswa. Jurnal Psikologi Vol Universitas Esa Unggul.

Liow, Cheryl Jocelyn. (2009). Hubungan Bullying Dengan Harga Diri Pada Remaja Siswa Sekolah Yang Menjadi Korban Bullying. Universitas Gunadar ma.publication. gunadarma.ac.i d27 Desember 2014.

Magfirah, Ulfah, dkk. (2011). Hubungan Antara Iklim Sekolah DenganKecenderungan Perilaku Bullying (diakses tanggal 27 Desember 2014).

Mudjijanti, F. (2011). "School Bullying dan Peran Guru Dalam Mengatasinya". Naskah Krida Rakyat. Madiun.: Universitas Katolik Widya Mandala.

Musbikin, Imam. (2012). Mengatasi Anak Mogok Sekolah Malas Belajar. Laksana: Yogyakarta.

Mustati, endah. (2005). Analisis Faktor Alat Ukur Kepribadian Big Five (adaptasi dari IPIP) Pada Mahasiswa suku Jawa. Jurnal INSAN vol.7 no 3 : universitas Airlangga

Notoadmodjo, S. (2012). Metodologi Penelitian Kesehatan. Rineka Cipta: Jakarta

Novianti, Ida. (2008). Fenomena Kekerasan Di Lingkungan Sekolah. Jurnal pemikiran alternatif pendidikan. Vol 13. No 2 : 324-338.: universitas STAIN Purwokerto

Nursalam, (2008). Konsep dan Penerapan Metodologi Penelitian Ilmu Keperawatan. Salemba Medika: Jakarta.

Ormrod, Jeanne Ellis. (2008). Psikologi pendidikan Edisi VI. Erlangga: Jakarta.

Santrock, J.W. (2007). Psikologi Pendidikan. Alih bahasa: Mila, dkk. Erlangga: Jakarta SEJIWA (Yayasan Semai Jiwa Amini). (2008). Mengatasi kekerasan dari sekolah dan lingkungan anak.Grasindo: Jakarta. 
Umasugi, Siti Chairani. (2012). Hubungan Antara Regulasi Emosi Dan Religiusitas Dengan Kecenderungan Perilaku Bullying PadaRemaja(www.academia.edu/Chachaumsss @ yahoo.c o.id27 Desember 2014).

Usman, Irvan. (2013). Perilaku BullyingDitinjau Dari Peran Kelompok Teman Sebaya Dan Iklim Sekolah Pada Siswa SMA Di Kota Gorontalo.repository.ung.ac. id diakses tanggal 27 Desember 2014.

Widiharto, Christhoporus Argo, dkk. (2009). Perilaku Bullying Ditinjau Dari Harga Diri Dan Pemahaman Moral

Anak.s2psikologi.tarumanagar FebruarI2014.
Yuswantina,Richa, dkk. (2013). Hubungan Antara Tipe Kepribadian Anak Dengan Perilaku Bullying Pada Siswa Kelas VIII Di SMP Negeri 1 Pati Kabupaten Pati. diakses tanggal 27 Desember 2014.

Yuniartiningtyas,Fitri.

Hubungan Antara Pola Asuh Dan Tipe Kepribadian Dengan Perilaku Bullying Di Sekolah Pada Siswa SMP. jurnalonline.um.ac.id diakses tanggal $26 \quad$ Juli 2015. 